\title{
The Aftermath of the Tariff War on China
}

\author{
Nicholas Bitar ${ }^{1}$ \\ ${ }^{1}$ Notre Dame University, Louaize \\ Correspondence: Nicholas Bitar. E-mail: nbitar@ndu.edu.lb \\ Received: December 4, 2019 \\ Accepted: December 31, 2019 Online Published: January 31, 2020 \\ doi:10.5539/ass.v16n2p22 \\ URL: https://doi.org/10.5539/ass.v16n2p22
}

\begin{abstract}
Will the US sustain its economy after the tariff war with China, or will the economy regress? This paper offers a conceptual framework, based on the tenets of New-Keynesian theory, to answer this question. I anticipate that the tariff will have a positive effect on the GDP of the US economy in the short run while prices will rise. When adding the most recent reforms of interest cut by the Fed to $1.75 \%$ in September (2019) the model concludes a better outcome. Followed by an expansionary monetary policy by reducing the interest rate, the aftermath of the tariff war on China seems to have a positive impact on the US income and productivity. Obviously, some critics to the Trump Administration indeed shed light on the curtailed global and US social welfare that is caused by the inflationary effect of the tariff war, in addition to the deteriorating conditions for some trading sectors in the US which would certainly lead to unemployment. But the benefits to the US economy that are translated by the New-Keynesian theoretical framework show a positive impact on US production, employment, and GDP.
\end{abstract}

Keywords: FDI, social welfare, GDP, tariff, unemployment, inflation and tariff war

\section{Introduction}

In 2018 the value of United States imports from China exceeded that of exports by $\$ 540$ billion. On the one hand, Americans benefit from lower-priced products that include industrial as well as consumer goods. On March 22, 2018, the US government imposed tariffs on US\$50-60 billion worth of Chinese goods. Over 1,300 categories of Chinese imports were listed. The justification of the tariff that would eventually impose is described as "purely defensive measures." The Trump administration claims that the cumulative trillions of dollars Americans transfer overseas as a result of yearly deficits are used by China to buy assets in America, in addition to any economic damage inflicted by intellectual property theft by pressuring foreign companies to transfer technology as a condition for securing investment. On April 2, 2018, The Ministry of Commerce of China retaliated by imposing tariffs on 128 products it imports from America. The tariff war kept escalating until June 29, 2019. During the G20 Osaka summit, Trump announced that he and Xi Jinping agreed to a "truce" in the trade war after extensive talks. Prior tariffs are to remain in effect, but no future tariffs are to be enacted "for the time being" amidst renewed negotiations. Economists are looking into likely effects of the trade war on the US economy. Will America sustain its economy after the tariff war or will the economy regress? We study the effect of the tariff on output within a New-Keynesian framework. The demand side of our model is based on an intertemporal consumption model of optimizing behavior by households over two-period allocations. Benigno (2015): The optimization condition equates the intertemporal marginal rate of substitution of consumption utility to the discounted relative price of future consumption utility. A standard Euler equation relates consumption growth to the real interest rate that concludes a negative association between prices and consumption. An increase in prices raises the real interest rate and consequently, consumers postpone their consumption due to an increase in the opportunity cost of spending thereby causing a reduction in the level of output. On the one hand, while Benigno (2015) looks at a closed economy, I allow international trade to capture the effect of import tax. In particular, I extend his model by incorporating Net Export (NX) that affects Aggregate Demand (AD).On the other hand; I use the Classical Philips curve to characterize Aggregate Supply (AS). Since in the short run it is assumed that wages are sticky, we expect a positive association between income and prices. In other words, as prices rise beyond the expected level in the light of sticky wages firms find the opportunity to increase their production taking advantage of higher prices but same the labor cost. Therefore, an increase in prices leads to more productivity in the short run. This is not the case in the long run, where AS is assumed to be vertical since wages become flexible and would adjust to changes in prices as well.

The structure of the article is the following. Section 2, I present the context of the paper. In this section, I 
highlight the aim of the trade war, the history, and the reported outcomes. Section 3 discusses the literature. Section 4 presents the formal framework of analysis and its graphical illustration. Section 5 analyzes the way the equilibrium changes when the tariff is imposed by the US government on imports from China and the retaliation position by the Chinese government. Section $6 \mathrm{I}$ include the effect of the interest rate reforms that were implemented by the FED in the month of September. In section 7 I present a thorough discussion over the finding that are presented in the literature and comparing them to my findings. Section 8 concludes.

\section{Context}

The US-China trade war is an ongoing conflict between two giant economies of the world. It all started when President Donald Trump in 2018 began a tariff imposition on China. The aim is to reduce the growing US trade deficit and prevent further theft of intellectual property by forcing the transfer of US technology to Chinese firms. Furthermore, Trump believes that trade war with China promotes domestic manufacturing and that would further reduce unemployment.

According to Alan Tonelson the US Business and Industry Council, a tariff is the only remedy against the US-China trade deficit in the light of the undervalued Chinese currency. Tonelson said, "nothing else has worked, nothing else will work".

In January 2018 Trump announced the first tariff round on solar panels and washing machines. After two months he added a tariff of $25 \%$ on steel followed by \$50-60 billion worth of Chinese goods. In April the Chinese Ministry of Commerce retaliated by imposing tariffs on 128 items imported from the US. In May Vice-premier LIU He and General Secretary of Chin XI Jinping visited Washington aiming to stop the trade war while committing to reduce the US trade deficit to China by significantly increasing the purchase of American goods. But that did not work well with Trump administration. In the same month, the White House announced a further tariff imposition of $25 \%$ on $\$ 50$ billion of Chinese goods. Furthermore, in July, they declared the second round of tariff increase including an additional 10\% tariff on $\$ 200$ billion worth of Chinese goods if China will retaliate against the preceding US tariffs on Chinese products. Consequently, China retaliated in the same month. In September China retaliated by imposing a $10 \%$ tariff of $\$ 60$ billion on US import goods. In the next year, in May 2019 Trump raised the previously $10 \%$ tariff on $\$ 200$ billion of Chinese imports to $25 \%$. This was followed by a tariff raise by China on goods worth $\$ 60$ billion in July of the same year. Chinese state-owned enterprises stopped buying US agricultural products totaling \$20 billion. Zippy Duvall, the president of the American Farm Bureau Foundation described that as "a body blow to thousands of farmers and ranchers who are already struggling to get by". In August, the Chinese Ministry of Finance imposed an additional tariff on US imports worth $\$ 75$ billion effective in September. As a result, Trump raised the tariff from 25\% to 30\% on the existing $\$ 250$ billion worth of Chinese goods.

For over a year the two countries have exchanged tit-for-tat tariffs. In September the Wall Street Journal reported that the US lumber mills are slashing employment as a result of the Chinese retaliatory tariffs on wood and lumber. In addition, Paul Krugman published in The New York Times July 2019“Trump is Losing His Trade War". He estimated that on average each US household is losing around $\$ 1000$ annually due to the trade war. Krugman added that the pain of the tariff is real to the American but the coercion to the trade partners will not happen for three reasons. China has dignity and it will never yield to the US bullying behavior. The second reason is that today all products are subject to global value chain hence, not buying from China does not necessarily bring production back home since not all components were produced in China in the first place. Hence, it is possible to provide components from a third party and assemble somewhere other than China or the US. And finally, the trade war will leave the Trump administration vulnerable to foreign retaliation.

It has been reported so far in the context of the aftermath of the US trade war, according to the American Farm Bureau agricultural exports to China declined from $\$ 24$ billion to $\$ 9.1$ billion in 2018 . To alleviate the difficulty, Trump allocated the sum of $\$ 28$ billion in direct payment to farmers. Whereas analysis made by Moody's Analytics estimated a 300,000 job loss or not created in the US due to the trade war. On the other hand, John Ferriola the CEO of Nucor, America's largest steel producer while interviewed by CNBC, argued that the tariff is fair "simply leveling the playing field". According to Ferriola, the $25 \%$ tariff is equivalent to the value-added tax that the European Union imposes on its people. Whether the tax is paid on import or upon sale to end-users, it is the same.

As a conclusion, practically no exact answer could be said about the aftermath of the trade war on the wellbeing of the US economy and trade deficit so far. Business people from different sectors could have opposite opinions. A tariff will always benefit some sectors mainly producers but will hurt others a good guess would be the importers of final goods. So their opinions are biased towards which sector they belong to. Similarly, 
policymakers could have different opinions as well. It is not to our surprise that all policy makers do have supporters and oppositions. So, different opinions are simply decided involuntarily by the biases of their minds. While economists also do have different points of view in that context, in the next section we come across some of these studies.

\section{Literature Review}

On the one hand, extensive trade with China is seen as a threat to the American economy, Asquith et al. (2017) concluded the China shock to be associated with the reduction of job offers due to a plant closing in sectors exposed to Chinese import competition. Moreover, more job contractions on minorities, blacks, and women. Bernards et al. (2003) while simulating the Ricardian model they concluded a $1 \%$ decline in trade barrier net employment declines by $0.26 \%$ due to plants that die or contract their production abroad. According to the basic demand and supply theory, imposing tariffs will increase the prices and local production but reduce local consumption due to higher prices. Yet the conclusion is that deadweight loss is created hence, a tariff with no doubts hurts the society by concluding a lower total surplus for a nation. But only if we disregard the fact that local production has increased and that contributes to higher national income. Almost the same finding was concluded from the Ricardian theory of comparative advantage, in the sense that the imposition of tariff over the trading nations will reduce specialization further and terms of trade will be renegotiated (shift leftward) and therefore a lower indifference curve. According to Bellora (2019) by using the dynamic general equilibrium model featuring global value chain, an expected increase in the prices of producer cost in the US which will translate into a loss of market shares of US firms on the global export market. Furthermore, a loss in GDP is expected for both nations for about $0.3 \%$. Hence, described Trump Administration tariff was as "shooting themselves in the foot". Jasper et al. (2018) study the robustness of the Lerner Symmetry in a two-country two goods framework following an open market New-Keynesian model with rigid prices and sticky wages. They concluded that trade wars do have a substantial effect on permanently lowering income and trade for both countries. According to Nicita et al. (2018), none cooperative tariff is positively correlated with the importers' market power. The intuition about this finding is that a large importer can improve their terms of trade by shifting the cost of production to the producer. They tested a theoretical framework for two nations with three goods for 92 WTO members for the optimal level of tariff in the presence of cooperation with no tariff water and none cooperation in the absence of tariff water. The results showed a significant positive relation between none cooperative tariffs with importers market power. In the presence of tariff water, the tariffs are set none cooperatively and in the presence of market, power encourages none cooperation while importer tends to increase tariff. Li et al. (2019) while testing the effect of the US trade protectionism over the US manufacturing employment, by using a General Equilibrium model using multi-sector multi-country model, also assuming capital and labor as the only factors of production with 2 goods manufacturing and none manufacturing goods and applying it to 29 major US exporting countries. The result shows that the overall effect will be a net loss for the US manufacturing employment especially if trade partners take retaliatory measures. The work shows a positive substitution effect of tariff between local and imported products but is outweighed by the negative substitution effect that is initiated from the retaliatory effects together with substitution between the manufacturing and service sectors. In other words, a US import tariff will protect local production by switching demand to local products instead. But the increase in price may shift consumption and production from manufacturing to service sectors. Lin and Wang (2018) used the value-added content discussed by Johnson and Noguera (2012) firms would fragment productivity and outsource intermediate inputs according to comparative advantage. It is a way to reduce costs and gain more profit. Hence, the value-added in trade flows is what matters rather than the overall trade value while testing the impact of trade on employment. Over the US historical trade deficit, they concluded the US major trade deficit to China is due to the comparative advantage of the labor-intensive manufacturing over other Eastern European countries. However, the overall trade deficit of the US relative to all Eastern Europe has declined since the 1990s. Hence, they predict that with time trade deficit with China will decline due to increasing in wage rate and yet President Trump's decision to impose tariffs on China is incorrect and will make little contribution to reducing the US trade deficit and improving internal jobs. On the other hand, Liu and Woo (2018) used the purchase power parity and price elasticity approach to prove that it is natural for a developing nation to have an undervalued exchange rate. So China does not intentionally set the undervalued exchange rate that further degrades the US trade deficit.

\section{Model}

A New-Keynesian model introduces the optimizing behavior of households and firms.

Benigno (2015) develops a two-period New-Keynesian model, the present period and the next period (the long run). Aggregate demand is obtained from households' decisions to optimally allocate consumption where 
households get utility from consumption and disutility from work. Hence a consumer utility function is given as

$$
u(c)-v(L)+\beta[u(\bar{c})-v(\bar{L})]
$$

Where $u(c)$ consumption utility increases with more consumption and $v(L)$ work utility diminished with more work. Yet $0<\beta<1$ is the discount factor of future utility flows.

Now household intertemporal budget constraint in which both periods spending PC (unit price times quantity of units consumed) must be equal to income WL (wage rate times labor hours) is given by the following expression.

$$
P C+\frac{\overline{P C}}{(1+i)}=W L+\frac{\overline{W L}}{(1+i)}
$$

Prices, wages, and interest rates are given in nominal terms. Also, next period spending and income are discounted by the nominal interest rate.

The optimization problem is captured by the Euler equation, which describes how households allocate consumption across the two periods, and that is

$$
\frac{u_{c}(C)}{p}=\frac{\beta u_{c}(\bar{c})(1+i)}{\bar{p}}=(1+r)
$$

The optimality condition (3) equates the marginal satisfaction per dollar today to the discounted (future utility flows) marginal satisfaction per dollar for spending in the second period compounded by the real interest rate (the return on investment).

Furthermore, by assuming isoelastic preferences the marginal utility of consumption is given as $u_{c}(c)=c^{-\partial^{-1}}$ where $\partial>1$ represents the intertemporal elasticity of substitution in consumption.

Now by substituting the isoelastic utility into the Euler equation and using the log form the equation (3) can be simplified as

$$
\bar{c}-c=\partial r+\partial \ln \beta
$$

Equation (4) shows a positive relationship between the real interest rate and future consumption. This result is well known in terms of the opportunity cost of present consumption with relation to the return on investment. In other words, as real interest rate increases, the opportunity cost of current period consumption rises and so consumption is likely to be postponed to the second period.

Finally, by using the closed economy Keynesian model of output determination $(\mathrm{Y}=\mathrm{C}+\mathrm{G})$ while also substituting the real interest rate by the nominal $r=i-(\bar{p}-p)$ for both periods Benigno (2015) derived the following equation for Aggregate Demand equation

$$
y=\bar{y}+g-\bar{g}-\partial i+\partial(\bar{p}-p)-\partial \ln \beta
$$

Equation (5) shows a negative relation between current price and income. The intuition behind equation (5) runs as follows. As the current price rises real interest rates will rise as well. Hence, consumers will postpone current consumption by saving more to benefit from a higher return on investment which would affect current income negatively.

So far, the model assumes a closed economy. By resting this assumption and adding trade we include net export to the model so that the Keynesian Model of Output Determination is $\mathrm{Y}=\mathrm{C}+\mathrm{G}+\mathrm{EX}-\mathrm{IM}$ for the current period and $\bar{Y}=\bar{C}+\bar{G}+\overline{E X}-\overline{I M}$ for the next or long-run period.

By integrating trade into the model we expand the aggregate demand as follows

$$
y=\bar{y}+g-\bar{g}-\partial i+\partial(\bar{p}-p)-\partial \ln \beta+N X-\overline{N X}
$$

Foreign demand for home exports (EX) is affected by two variables, foreign income which in this case is exogenous, and the price of local products to be exported to foreign market relative to their prices in the foreign markets $\left(p_{f}\right)$. Let $\frac{e}{p}$ denotes the price of the local product converted into the foreign currency where e is the exchange rate per foreign currency. Now the decision for foreigners to buy a product is based on the relative prices of the domestic comparable product. Then the price ratio is $\frac{e p_{f}}{p}$. Moreover, according to the foreign country which in this case is China, imports from the US are affected by the home prices together with the tariff 
$\alpha$ imposed by the Chinese government as the retaliation plan. So according to the Chinese importers, the US prices are multiplied by the Chinese import tax rate $\alpha$. Therefore the real relative price ratio for US export adjusted for foreign tariff inclusion is summarized as $\frac{e p_{f}}{\alpha p}$. There is a positive relationship between export and foreign prices and the inverse relation between export and home prices. That implies US exports is $E X=\frac{z e p_{f}}{\alpha p}$ where $z$ is the sensitivity of export to the relative price difference. And $\alpha$ is the mark up over the price of the home products imposed by foreign nation tariff imposition. Where $\alpha \geq 1$ that is whenever no tariff is imposed by the foreign nation then $\alpha=1$ on the other hand a positive tariff imposed by the foreign nation say in the latter case that China imposes a tariff of $25 \%$ on US imported products, then $\alpha=1.25$.

Now US imports (IM) are directly related to income, with more income more demand for consumption and so more foreign products are demanded. Moreover, there is an indirect relation between foreign prices and US imports. Similar to exports, import prices must be converted to local currency using the spot exchange rate that is $\frac{e p_{f}}{p}$. But also imports are affected by the tariff imposed by the US government as declared by President Trump. Now let tariff imposed by the home country be denoted by ţ and $x$ is the US import sensitivity to relative price difference among US and China. So the relation between US imports and foreign prices is $\frac{e x t p_{f}}{p}$. This expression includes the relative prices of foreign products to home products including a tariff on imports imposed by the US. Hence, $I M=m y-\frac{x p_{f} e}{p}$ where $m$ is the sensitivity of US income effect to foreign product demand. Where $x>1, x$ is assumed to be positive and sensitive that is, the substitution for Chinese products to US citizens is highly elastic to price changes. This assumption is valid by default since no compelling literature work has been done so far. The same assumption can pertain about the sensitivity of Chinese import to price changes (variable z). Hence, both nations' sensitivities could be treated as sensitive and identical that is $x \cong z$.

Now we get the net export expression as follows:

$$
N X=\frac{x \mathfrak{t e} p_{f}}{p}-m y+\frac{z p_{f} e}{\alpha p}
$$

Therefore, the next period export equation is:

$$
\overline{N X}=\frac{x \overline{\mathrm{t}} \overline{\overline{p_{f}}}}{\bar{p}}-m \bar{y}+\frac{z \overline{e_{f}}}{\bar{\alpha} \bar{p}}
$$

Thus, both periods net export given as $(N X-\overline{N X})$

We get the following expression

$$
(N X-\overline{N X})=\frac{e}{p}\left(x \mathrm{t} p_{f}+\frac{z p_{f}}{\alpha}\right)-m(y-\bar{y})-\frac{\bar{e}}{\bar{p}}\left(x \overline{p_{f} \overline{\bar{t}}}+\frac{z \bar{p}_{f}}{\bar{\alpha}}\right)
$$

Here we incorporate both periods' net export difference into equation (6).

We get the following Aggregate Demand equation

$$
y=\bar{y}+\frac{(g-\bar{g})}{(1+m)}-\frac{\partial(i-\bar{p})}{(1+m)}-\frac{\partial p}{(1+m)}+\frac{e p_{f}\left(x \grave{t}+\alpha^{-1} z\right)}{p(1+m)}-\frac{\overline{e p_{f}}\left(x \bar{\zeta}+\bar{\alpha}^{-1} z\right)}{\bar{p}(1+m)}-\frac{\partial \ln \beta}{(1+m)}
$$

Now, $\frac{d y}{d p}=-\frac{1}{1+m}\left(\partial+\frac{e p_{f}}{p^{2}}\left(x t+\alpha^{-1} z\right)\right)<0$ : As expected, there is a negative relationship between income and price. 
Now for the Aggregate Supply, we use the short-run aggregate supply equation AS: $y=y^{*}+k\left(p-p_{e}\right)$ since we assume wage stickiness. Note that $k>0$. Hence, $\frac{d p}{d y}=\frac{1}{k}$ i.e. the AS curve has a positive slope.

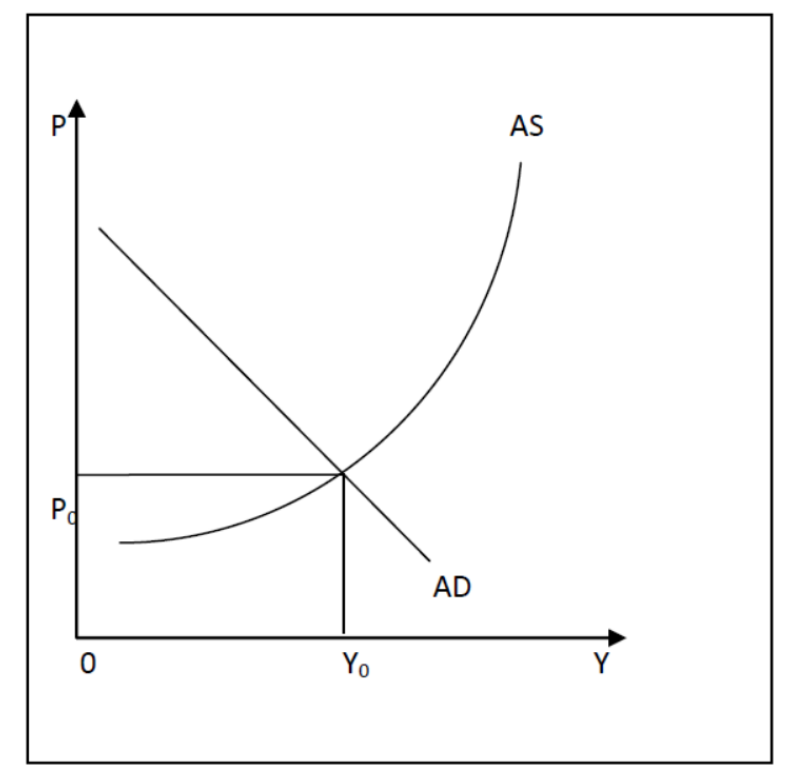

Figure 1.

\section{Effect of Tariff War on the AD/AS Equilibrium}

Our concern is the tariff that was imposed by the US government on imported products from China on the one hand, and the Chinese tariff that was imposed on the US suppliers as a retaliation plan. To begin with, the effect of the tariff imposed by the US government is given as

$\frac{d y}{d \underline{t}}=\frac{x e p_{f}}{p(1+m)}>0$.This implies a rightward shift in the aggregate demand as the prices of foreign goods becomes more expensive due to tariff. On the other hand, the retaliation plan by the foreign nation implies an increase in the tariff imposed by the foreign nation over the home country exports, the retaliation expression is, $\frac{d y}{d \alpha}=$ $\frac{-z e p_{f}}{p \alpha^{2}(1+m)}<0$

According to Li et al. (2019), while using a canonical GTAP in GAMS model to conduct sensitivity analysis using one or two standard deviations, they reported for the first round of tariffs by September 2019 a trade-weighted average tariff for the US on Chinese exports to be $21.7 \%$ whereas the Chinese retaliation on US exports $20.7 \%$. Based on Li et al. (2019) we can predict an identical tariff change by both nations. Hence, adding both effects simultaneously also given that both nations have imposed approximately the same tariff on one another we get $d t \mathrm{t}=d \alpha$ therefore the net effect of the trade war on the US is given as

$$
d y=d \mathrm{t} \frac{e p_{f}}{p(1+m)}\left(x-\frac{z}{\alpha^{2}}\right)
$$

Equation (11) leads to a rightward shift in aggregate demand as long as $x \cong z$. That must be the case since the sensitivity of the US import to relative price changes is identical to the Chinese sensitivity to import to relative price changes as well. Implies $\frac{d y}{d \mathfrak{t}}=\frac{e p_{f}}{p(1+m)}\left(x-\frac{z}{\alpha^{2}}\right)>0$ Figure 2 shows the rightward shift in aggregate demand due to the trade war. Following the rightward shift in aggregate demand, disequilibrium is created in the AD/AS. 
Obvious aftermath is that prices start rising in the local market as a response to an increase in demand for local production in the US. So production starts increasing by $\frac{1}{k}$ at the same time reduction in local consumption due to a rise in local prices (upward movement along the new aggregate demand curve)

$\frac{d y}{d p}=-\frac{1}{1+m}\left(\partial+\frac{e p_{f}}{p^{2}}\left(x t+\alpha^{-1} z\right)\right)$ until a new equilibrium is reached at $\mathrm{P}_{1}$ and $\mathrm{Y}_{1}$. What is certain about the new equilibrium is the fact that it must be at a higher price due to tariff also output $\mathrm{Y}$ will rise as well in the short run to $Y_{1}$ taking advantage of sticky wages but higher prices.

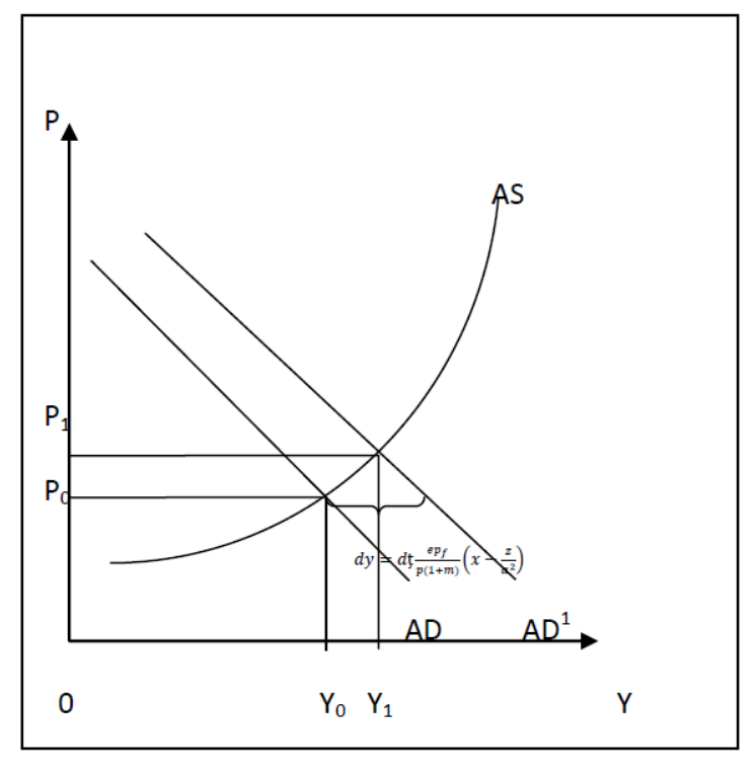

Figure 2.

\section{Effect of Interest Changes on the Overall Equilibrium}

In September(2019), the Federal Reserve cut interest rates to current levels 1.75\%, after the highest record of $2.5 \%$ in December (2018). Now we add the effect of the interest rate cut that was imposed by the Fed. The effect of a decrease in the interest rate is given by $\frac{d y}{d i}=\frac{-\partial}{(1+m)}<0$. Hence the aggregate demand will further shift to the right as the Fed reduces the interest rate. Therefore we predict the expansionary monetary policy that is imposed by the Fed to amplify the effect of the tariff imposed on trade by both nations. By combining the effect of trade war equation (9) with interest effect we get the following expression

$$
d y=d \mathrm{t} \frac{e p_{f}}{p(1+m)}\left(x-\frac{z}{\alpha^{2}}\right)+\frac{-\partial}{(1+m)} d i
$$

The sign of equation (12) is certainly positive. The increase in tariff has a positive impact on the first part of equation (12), followed by a decrease in interest rate that also has a positive effect on the second part of equation (12), that leads to a rightward shift in the aggregate demand by $d y=d \mathrm{t} \frac{e p_{f}}{p(1+m)}\left(x-\frac{z}{\alpha^{2}}\right)+\frac{-\partial}{(1+m)} d i$ instead of

$$
d y=d \mathfrak{t} \frac{e p_{f}}{p(1+m)}\left(x-\frac{z}{\alpha^{2}}\right) \text { Hence, the reduction in interest rate will magnify the tariff effect by } \frac{\partial}{(1+m)} d i .
$$

\section{Discussion}

My results confirm Asquith et al. (2017) expansion in trade with China reduces job offers due to plant closing in sectors exposed to Chinese import competition. Trade war reduces the trade between both nations. Hence US sectors who were highly exposed to Chinese imports now do have the opportunity to expand production and hiring more employees. Certainly, that will improve employment, production, and output. Similar results were derived by Bernards et al. (2003) who concluded a 1\% decline in trade barrier net employment declines by $0.26 \%$ 
due to plants that die or contract their production abroad. The results of this paper confirm the basic demand and supply theory, the imposed tariff will increase the prices and local production. Yet the conclusion is that deadweight loss is created. Hence, the tariff will hurt society by concluding a lower total surplus for a nation. But only if we disregard the fact that local production has increased and that contributes to higher income.

Alternatively, my finding contradicts Bellora (2019) expecting an increase in the prices of producer cost in the US which will translate into the loss of market shares of US firms on the global export market in addition to a loss in US GDP for about $0.3 \%$. This could be valid for firms that import intermediate goods from China while assuming no equal alternative. But it is worthwhile mentioning that new opportunities for new local production must be taken into account. Moreover, Li et al. (2019), by using a General Equilibrium model using multi-sector multi-country model with 2 goods manufacturing and none manufacturing goods. The result shows that the overall effect will be a net loss for the US manufacturing employment especially if trade partners take retaliatory measures. Though the work shows a positive substitution effect of tariff between local and imported products but is outweighed by the negative substitution effect that is initiated from the retaliatory effects together with substitution between the manufacturing and service sectors. They base their outcome on the fact that higher prices will entail substituting consumption of local products into service sectors. In that case, local production will not be expanded and results will be similar to a negative supply shock. But is the US heading towards a negative supply shock? Is the Trump Administration unaware of such an outcome of the trade war on China? My best guess is no. A negative supply shock is not necessary for the case here.

\section{Conclusion and Recommendation}

This theoretical framework shows that the trade war that was initiated by the US government to reduce import based on the New Keynesian model of output determination is expected to have a short run positive effect over the US economy, though prices are expected to rise yet, some unusual growth should be seen in the short-run. By including the Federal Reserve interest cut to $1.75 \%$ in September our results show more robust results. Unfortunately, we do not have adequate data to validate the finding at this time. Hence, further studies may quantify the real effect of the tariff war including the interest rate reforms by the Fed and the long-run effect while wages become flexible and labor cost rise following the inflation as predicted by the Keynesian long-run vertical aggregate supply curve. One limitation of this model is that it does not take into consideration the fact that US companies are shifting production to other countries such as Argentina and Brazil instead of moving production back home.

\section{References}

Agnes, B. Q., Matthieu, B., \& Pauline, W. (2018). Trade and Currency Weapons. Center of Economic Studies and IFO Institute. Working paper No. 7112. https://ssrn.com/abstract=3235196

Alessandro, N., Marcelo, O., \& Peri, S. (2018). Cooperation in WTO's Tariff Water. Journal of Political Economy, 126(3). http://dx.doi.org/10.1086/697085

Bellora, C. (2019). Shooting Oneself in the Foot? Trade War and Global Value Chains. Centre d'Economie de la Sorbonne, 106-112.

Benigno P. (2015). New-Keynesian Economics: An AS-AS View. Research in Economics, 69(4), 503-524 https://doi.org/10.1016/j.rie.2015.07.005

Bernard, A. B., Eaton, J., Jensen, J. B., \& Kortum, S. (2003). Plants and Productivity in International Trade. American Economic Review, 93(4), 1268-1290.

Brian, A., Sanjana, G., David, N., \& Antonio, R. L. (2017). US. Job Flows and the China Shock. Journal of International Economics, 118, 123-137. https://doi.org/10.1016/j.jinteco.2019.02.002

Chunding, L., Wang, J., \& Whalley, J. (2019). Trade Protectionism and US Manufacturing Employment. National Bureau of Economic Research, NBER Working Paper No. 25860 DOI 10.3386/w25860

Fetzer, T., \& Carlo, S. (2019). Tariffs and Politics: Evidence from Trump's Trade wars. Center of Economic Studies and IFO Institute. Working paper No. 7553. http://dx.doi.org/10.2139/ssrn.3349000

Lin, Y. J., \& Wang, X. (2018). Trump Economics and China-US Trade Imbalances. Institute of New Structural Economics, working paper series No. E2018002. http://www.nber.org/papers/w25860

Linde, J., \& Andrea, P. (2019). The Macroeconomic Effect of Trade Tariff: Revisiting the Lerner Symmetry Result. Sveriges Riksbank, working paper series No. 363. https://doi.org/10.1016/j.jimonfin.2019.01.019

Minghao, L., Balistreri, E., \& Zhang, W. (2019). The U.S.-China trade war: Tariff data and general equilibrium 
analysis. Center for Agriculture and Rural Development, working paper series No. 19-WP 595

Nana, G., \& Bastiaan, V. (2018). US-China relations and the Liberal Words Order: Contending Elites, Colliding Visions. International Affairs, 94(1), 113-131. https://doi.org/10.1093/ia/iix23

Tao, L., \& Woo, W. T. (2018). Understanding the US-China Trade War. China Economic Journal. https://doi.org/10.1080/17538963.2018.1516256

\section{Copyrights}

Copyright for this article is retained by the author(s), with first publication rights granted to the journal.

This is an open-access article distributed under the terms and conditions of the Creative Commons Attribution license (http://creativecommons.org/licenses/by/4.0/). 